\title{
KOORDINASI KEBIJAKAN MONETER DAN FISKAL DI INDONESIA: SUATU KAJIAN DENGAN PENDEKATAN GAME THEORY
}

\author{
Iskandar Simorangkir ${ }^{1}$
}

\begin{abstract}
A bstrak
Perdebatan hubungan kebijakan moneter dan fiskal terkait dengan dampak defisit anggaran yang dapat mengganggu inflasi yang merupakan tujuan akhir kebijakan moneter. Sebaliknya, bagi pembuat kebijakan fiskal inflasi yang terlalu ketat dapat berdampak buruk terhadap pertumbuhan ekonomi dan kesempatan kerja yang merupakan tujuan utama dari kebijakan fiskal. Tidak terdapatnya koordinasi diantara kedua kebijakan tersebut dapat berdampak terhadap stabilitas makro dan pertumbuhan ekonomi.

Paper ini akan membahas koordinasi kebijakan moneter dan fiskal di Indonesia dari tahun 1969 hingga tahun 2002 dengan menggunakan pendekatan game teori baik berupa cooperative dan noncooperative game. Beberapa kerangka permainan akan disimulasikan dengan model ekonometrik dengan waktu yang kontinu. Pembuat kebijakan moneter dan fiskal diasumsikan mempunyai fungsi tujuan yang berbeda. Dalam mencapai tujuan tersebut, mereka dapat bekerjasama atau tidak. Hasil simulasi menunjukkan bahwa cooperative game memberikan hasil kerugian terkecil (lost function) dibandingkan dengan non-cooperative game.
\end{abstract}

Keywords: Game Theory, Koordinasi, Kebijakan moneter dan fiskal

JEL Classification: C71, C72, E63

1 Peneliti Madya Senior di Pusat Pendidikan dan Studi Kebanksentralan, Bank Indonesia Email: iskandarsim@bi.go.id dan iskandarvandy@yahoo.com. Penulis mengucapkan terimakasih kepada Dupit, mahasiswa magang FE UI atas bantuan pengelolaan data dan peserta seminar call for papers PPSK-FE UI tahun 2005 


\section{KOORDINASI KEBIJAKAN MONETER DAN FISKAL DI INDONESIA: SUATU KAJIAN DENGAN PENDEKATAN GAME THEORY}

\section{Latar Belakang}

Pembahasan mengenai pentingnya koordinasi antara kebijakan moneter dan fiskal telah lama menjadi topik perhatian serius baik di negara-negara maju maupun negara berkembang. Sebagian ekonom sepakat bahwa dengan adanya koordinasi kebijakan moneter dan fiskal akan berdampak positif terhadap stabilitas makroekonomi. Sebagian ekonom yang lain berpendapat bahwa sebaiknya kedua otoritas kebijakan tersebut tidak memperhatikan tingkah laku otoritas kebijakan yang lain karena dengan koordinasi tujuan kebijakan moneter dan fiskal tidak dapat dilakukan secara optimal.

Perdebatan mengenai hubungan antara otoritas moneter dan fiskal terfokus pada masalah inflasi yang merupakan konsekuensi pembiayaan yang dilakukan oleh bank sentral dalam menutup defisit fiskal pemerintah. Pembiyaan fiskal defisit yang berlebihan dapat mengakibatkan terjadinya peningkatan laju inflasi yang sangat tinggi (hyper inflation) dan pada lanjutannya dapat mendorong perekonomian ke dalam resesi ekonomi. Menyadari efek berbahaya dari inflasi bagi perekonomian, pada umumnya pemerintah mengendalikan pengeluaran fiskal melalui peningkatan penerimaan khususnya yang berasal dari pajak.

Pengalaman empiris negara-negara di Amerika Latin pada akhir tahun 1980-an menunjukkan bahwa pembiayaan fiskal defisit yang besar dan terjadi terus menerus melalui penciptaan uang baru oleh bank sentral telah mengakibatkan negara-negara tersebut mengalami hiper inflasi dan resesi ekonomi yang dalam. Pengalaman Indonesia pada tahun 1960-an juga menunjukkan kejadian yang sama dan bahkan akibat tingginya laju inflasi uang rupiah dipotong (sanering) nilainya.

Pengalaman beberapa negara termasuk Indonesia menyadarkan pembuat kebijakan untuk melakukan koordinasi. Koordinasi kedua kebijakan tersebut secara harmonis dapat meningkatkan social welfare masyarakat secara optimal. Dengan koordinasi, defisit pengeluaran pemerintah dapat terkendali sehingga laju inflasi dapat dicapai pada tingkat yang rendah dan pertumbuhan ekonomi yang berkesinambungan dapat dicapai.

Sebaliknya, beberapa ekonom berpendapat bahwa pembiayaan defisit fiskal pemerintah oleh bank sentral sebagai akibat kuatnya hubungan antara pemerintah dengan bank sentral dapat berbahaya bagi perekonomian. Kuatnya hubungan tersebut mengakibatkan bank sentral tidak kuasa menolak permintaan pemerintah untuk memberikan pinjaman kepada pemerintah. 
Dengan didasari pemikiran tersebut, sebagian ekonomi berpendapat sebaiknya kebijakan moneter dan fiskal berdiri sendiri sehingga keduanya dapat saling koreksi atas penyimpangan kebijakan di masing-masing otoritas moneter dan fiskal.

Sejalan dengan pemikiran di atas, penelitian ini akan membahas mengenai perkembangan dan dampak kooordinasi kebijakan moneter dan fiskal di Indonesia. Setelah bab pendahuluan ini, pada bab dua akan dibahas teori dan hasil empiris koordinasi kebijakan moneter dan fiskal. Selanjutnya, pada bab tiga akan dibahas perkembangan koordinasi kebijakan moneter dan fiskal di Indonesia. Bab empat akan membahas data dan model. Bab enam akan menguraikan hasil empiris penelitian. Bab enam merupakan bab penutup yang akan memaparkan kesimpulan dan implikasi kebijakan dari temuan di dalam pembahasan.

\section{Landasan Teoritis Koordinasi Kebijakan Moneter dan Fiskal II.1. Koordinasi Kebijakan Moneter dan Fiskal}

Perdebatan pentingnya koordinasi antara kebijakan moneter dan fiskal pada dasarnya tidak terlepas dari terdapat perbedaan penekanan dalam pencapaian tujuan masing-masing kebijakan. Tujuan utama kebijakan moneter lebih ditekankan pada stabilitas harga, dengan dasar beberapa pertimbangan. Pertama, dengan output ditentukan kapasitas ekonomi dalam jangka panjang maka segala kebijakan yang mendorong pertumbuhan ekonomi akan menciptakan inflasi (the short-run Phillips-curve) sehingga tidak akan mempengaruhi pertumbuhan ekonomi riil (Kydland and Prescott, 1997). Kedua, rational economic agent mengerti bahwa tindakan kejutan pembuat kebijakan dalam mendorong pertumbuhan ekonomi yang mendorong inflasi dapat mendorong terjadinya permasalahan time-consistency (Barro and Gordon, 1983). Ketiga, Kebijakan moneter mempengaruhi variabel ekonomi memakan waktu panjang dan mempunyai lag (Friedman, 1968). Keempat, kestabilan harga dapat mendorong terciptanya iklim ekonomi yang lebih baik karena akan mengurangi biaya yang berasal dari inflasi.

Penetapan stabilitas harga sebagaimana dikemukakan di atas akan mendorong kesinambungan pertumbuhan ekonomi dalam jangka panjang. Namun di sisi lain jika pencapaian kebijakan moneter tidak dilakukan secara terukur juga dapat mengakibatkan tekanan terhadap pertumbuhan ekonomi. Misalnya, kebijakan moneter yang terlalu ketat dapat menekan (sequeze) pertumbuhan ekonomi dan meningkatkan jumlah pengangguran.

Sementara itu, tujuan kebijakan fiskal yang mengutamakan pertumbuhan ekonomi dapat mengakibatkan terjadinya defisit anggaran yang dapat membahayakan stabilitas ekonomi makro. 
Dampak dari defisit fiskal yang kronis dan besarnya utang pemerintah dapat menimbulkan beberapa akibat (Traclet, 2004). Pertama, Fiskal defisit dapat meningkatkan rasio utang sehingga dapat meningkatkan beban utang dan menurunkan investasi yang produktif. Kedua, Peningkatan jumlah bond yang dikeluarkan untuk menutup fiskal defisit akan menciptakan crowding-out effect, yaitu penurunan investasi swasta yang produktif, sehingga membahayakan kelangsungan pertumbuhan ekonomi. Ketiga, defisit anggaran pemerintah yang kronis dapat mengakibatkan tingginya inflasi.

Pengalaman empiris di negara-negara Amerika Latin, negara Afrika dan negara mantan eropa timur pada tahun 1988-1991 menunjukkan bahwa fiskal defisit yang kronis dalam rangka mendorong pertumbuhan ekonomi telah mengakibatkan terjadinya hyper-inflation di negaranegara tersebut. Defisit fiskal yang dibiayai dari penciptaan uang telah mengakibatkan pesatnya pertumbuhan uang beredar dan selanjutnya hal tersebut telah mengakibatkan meroketnya laju inflasi di negara-negara tersebut.

Pada tabel II. 1 terlihat fiskal defisit pemerintah Peru telah mengakibatkan peningkatan jumlah uang beredar sebesar 1.052,6\% per tahun pada periode tahun 1988-1991. Pesatnya pertumbuhan uang beredar tersebut tanpa diikuti peningkatan produksi merupakan penyebab melesatnya laju inflasi di negara tersebut hingga mencapai 1.694,3\%. Hiper inflasi telah mengakibatkan anjloknya daya beli masyarakat dan tingginya biaya transaksi ekonomi sehingga negara tersebut jatuh ke dalam resesi ekonomi. Pengalaman negara-negara Afrika, beberapa negara Eropa dan negara-negara Amerika Latin lainnya mengikuti pola yang sama, yaitu fiskal defisit telah mengakibatkan tingginya uang beredar dan hiper inflasi.

Tabel II.1.

Pertumbuhan Uang Beredar dan Laju Inflasi di Beberapa Negara (1988-1991)

\begin{tabular}{c|c|c|c} 
No. & Negara & $\begin{array}{c}\text { Pertumbuhan Uang } \\
\text { Beredar \% tahunan) }\end{array}$ & $\begin{array}{c}\text { Tingkat Inflasi } \\
\text { (\% tahunan) }\end{array}$ \\
1 & Peru & 1052,6 & 1694,3 \\
2 & Zaire & 207,7 & 251,4 \\
3 & Polandia & 144,9 & 184,7 \\
4 & Uruguay & 78,3 & 88,3 \\
5 & Mexico & 67,0 & 41,4 \\
6 & Turki & 57,4 & 66,2 \\
7 & Zambia & 56,6 & 94,7 \\
8 & Ecuador & 50,8 & 57,4 \\
9 & Sudan & 50,8 & 78,5 \\
10 & Nigeria & 36,6 & 29,6
\end{tabular}


Beberapa data empiris di atas menunjukkan bahwa kebijakan fiskal yang longgar dengan kebijakan moneter yang longgar melalui penciptaan uang baru untuk pembiayaan defisit dapat mengakibatkan terjadinya hiper inflasi dan gangguan stabilitas makroekonomi. Sejalan dengan beberapa fakta tersebut maka diperlukan koordinasi kedua kebijakan tersebut.

Beberapa penelitian empris telah dilakukan untuk mengetahui dampak dari koordinasi kebijakan moneter dan fiskal terhadap perekonomian. Pendekatan populer yang sering digunakan adalah pendekatan teori permainan (game theory) untuk mengetahui ketiadaan koordinasi kebijakan fiskal dan moneter.

Secara teoritis, terdapat empat jenis hasil yang didapatkan dari kebijakan bauran (policy mix) dari kebijakan moneter dan fiskal jika keputusan dilakukan secara bebas satu dengan lainnya (independent), yaitu:

1. Kebijakan fiskal longgar dan kebijakan moneter longgar

2. Kebijakan fiskal longgar dan kebijakan moneter ketat

3. Kebijakan fiskal ketat dan kebijakan moneter longgar

4. Kebijakan fiskal ketat dan kebijakan moneter ketat

Hasil dari keempat bauran kebijakan (policy mix) tersebut dapat disajikan dalam tabel sebagai berikut:

Tabel II.2.

Bauran Kebijakan (Policy mix) Moneter dan Fiskal

Kebijakan Moneter Longgar

Kebijakan Moneter Ketat

\section{Kebijakan Fiskal Longgar}

Hasil: Efektif

Hasil: Saling Meniadakan
Kebijakan Fiskal Ketat

Hasil: Saling Meniadakan

Hasil: Efektif

Berdasarkan analisis IS-LM seperti tabel II.2 di atas, terdapat bauran kebijakan yang memberikan hasil yang efektif, yaitu 1) kebijakan moneter longgar dan kebijakan fiskal longgar, dan 2)kebijakan moneter ketat dan kebijakan fiskal longgar. Sementara itu, bauran kebijakan moneter ketat dan kebijakan fiskal longgar, dan bauran kebijakan moneter longgar dan kebijakan ketat akan memberikan hasil saling meniadakan.

Bauran kebijakan dalam kerangka IS-LM di dasarkan atas masih belum mempertimbangkan peranan koordinasi sehingga masing-masing bertindak independent. Untuk melihat lebih jauh dampak dari koordinasi keuda kebijakan terhadap kinerja makroekonomi maka akan digunakan pendekatan teori permainan (game theory). Untuk mengenal lebih jauh tentang pendekatan game theory dalam menganalisa efek ketiadaan koordinasi kebijakan 
pada kondisi makroekonomi, penulis membuat suatu monetary-fiscal game lengkap dengan hasil yang akan didapatkan dan kerugian yang haris dibayar oleh masing-masing otoritas, seperti ditunjukan oleh gambar di bawah ini (Bennett dan Loayza, 2002):

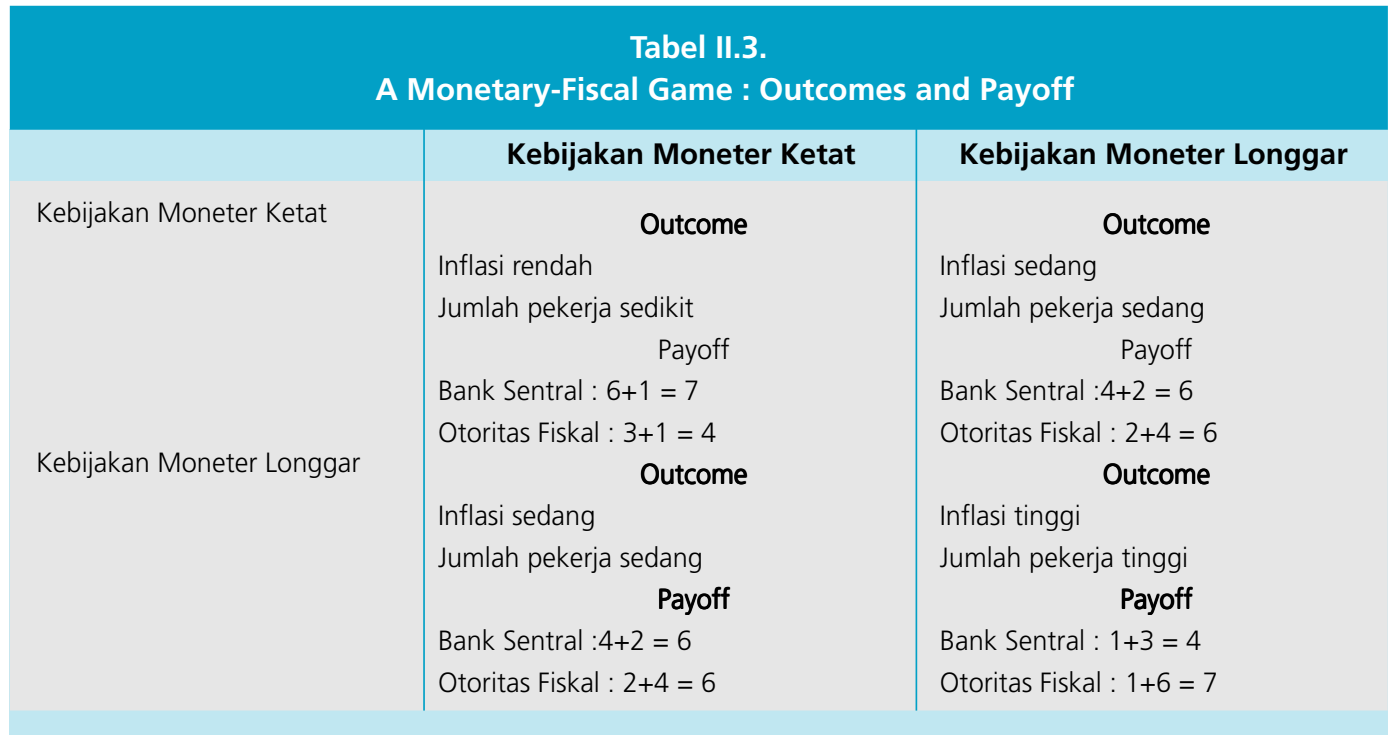

Berdasarkan tabel II.3 diatas, diasumsikan bahwa setiap otoritas kebijakan memiliki dua pilihan kebijakan, yaitu : kebijakan pengetatan maupun kebijakan pelonggaran (a tight or a loose policy). Ketika keduanya bersama-sama memilih kebijakan pengetatan maka akan menghasilkan keadaan perekonomian dimana tingkat inflasi cenderung rendah dan jumlah pekerja yang rendah atau pengangguran tinggi, sedangkan ketika kedua otoritas kebijakan memutuskan untuk bersama-sama membuat kebijakan yang longgar maka mengakibatkan tingkat inflasi meningkat sedangkan angka pengangguran cenderung rendah. Sedangkan ketika salah satu otoritas kebijakan membuat kebijakan pengetatan sedangkan yang lain membuat kebijakan pelonggaran dan sebaliknya, maka tingkat pengangguran dan inflasi cenderung berada pada tingkat sedang.

Nash Equilibrium pada game ini terdiri dari kebijakan moneter ketat dan kebijakan fiskal longgar. Jika kita melihat table Payoff schedule diatas, ternyata nilai payoff untuk kebijakan moneter ketat dan kebijakan fiscal longggar (yang juga merupakan solusi dari Nash Equilibrium) sama dengan nilai payoff untuk kebijakan moneter longgar dan kebijakan fiscal ketat. Namun dalam jangka panjang, kombinasi kebijakan moneter longgar dan fiskal ketat lebih sehat daripada kebijakan moneter ketat dan fiskal longgar (Nash Equilibrium). Hal ini disebabkan kebijakan tersebut tidak berkompromi terhadap fiscal sustainability dan tidak memperlemah kapasitas investasi sektor swasta. 
Penelitian empiris dengan menggunakan teori permainan yang dilakukan Petit (1989), Bannet dan Loayza (2002), Bartolomeo dan Gioacchino (2004), serta Faure (2004) menunjukkan bahwa koordinasi memberikan hasil yang lebih baik bagi perekonomian dibandingkan dengan hasil tidak terdapat koordinasi antara kebijakan moneter dan kebijakan fiskal.

\section{II.2. Teori Permainan}

Model teori permainan menekankan efek dari perbedaan preferensi dari otoritas kebijakan moneter dan fiscal pada tingkat defisit fiskal dan tingkat suku bunga riil. Pendekatan game theory diperkenalkan oleh Frankel (1988), Loewy (1988) dan Nordhaus (1994). Berdasarkan model Frankel, diasumsikan bahwa kedua otoritas kebijakan memiliki preferensi yang sama pada pencapaian tingkat inflasi dan output yang optimal. Berdasarkan model Nordhaus diasumsikan bahwa otoritas moneter tidak suka mengganti tingkat suku bunga riil ke level optimal.

Dalam model diasumsikan jika setiap pembuat kebijakan akan berusaha untuk memaksimasi fungsi ulilitasnya. Selain itu, diasumsikan bahwa setiap otoritas tidak suka merubah instrument kebijakan mereka dari level equilibrium. Sehingga fungsi utilitas dari otoritas fiskal ditunjukan oleh persamaan berikut ini:

$$
\begin{aligned}
& U^{F}=V^{F}\left[\left(y-y^{*}\right),\left(\pi-\pi^{*}\right),\left(D-D^{*}\right)\right] \\
& U^{F}=-\alpha^{F}\left[\min \left(y-y^{*}, 0\right)\right]^{2}-\beta^{F}\left[\max \left(\pi-\pi^{*}, 0\right)\right]^{2}-\delta\left(D-D^{*}\right)^{2} \\
& \alpha^{F}, \beta^{F}, \delta^{F}>0
\end{aligned}
$$

dimana, $U^{F}$ merupakan level utilitas untuk otoritas fiskal, $\alpha^{F}, \beta^{F}, \delta^{F}$ merupakan koefisien relative dari preferensi diantara kebijakan-kebijakan, $\left(y-y^{*}\right)$ adalah ambang batas biaya penurunan tingkat output, $\left(x-x^{*}\right)$ peningkatan inflasi yang melampaui level yang diinginkan, sedangkan $D$ - $D^{*}$ merupakan penyimpangan defisit fiskal dari socially optimal level.

Sementara itu, fungsi utilitas moneter ditunjukan oleh persamaan di bawah ini :

$$
\begin{aligned}
& U^{M}=V^{M}\left[\left(y-y^{*}\right),\left(\pi-\pi^{*}\right),\left(r-r^{*}\right),\right] \\
& U^{M}=-\alpha^{M}\left[\min \left(y-y^{*}, 0\right)\right]^{2}-\beta^{M}\left[\max \left(\pi-\pi^{*}, 0\right)\right]^{2}-\tau\left(r-r^{*}\right)^{2} \\
& \alpha^{M}, \beta^{M}, \tau>0
\end{aligned}
$$

dimana, $U^{M}$ merepresentasikan utilitas dari otoritas moneter, $\left(r-r^{*}\right)$ merupakan penyimpangan tingkat suku bunga riil dari socially optimal level. Asumsi bahwa $\tau>0$ merefleksikan observasi bahwa bank sentral tidak menyukai pergerakan secara besar dan tiba-tiba pada kebijakan 
tingkat suku bunga. Sama halnya dengan asumsi bahwa nilai $\delta>0$ menggambarkan fakta bahwa otoritas fiscal tidak menyukai penyimpangat instrument mereka dari target yang sudah ditentukan.

Otoritas moneter diasumsikan lebih peduli tentang adanya peningkatan inflasi daripada otoritas fiscal. Sebaliknya otoritas fiscal lebih peduli terhadap adanya penurunan tingkat output jika dibandingkan dengan otoritas moneter, sehingga menyebabkan $\beta^{M}>\beta^{F}$ dan $\alpha^{F}>\alpha^{M}$. Perbedaan preferensi ini menggambarkan misi dari bank sentral dalam mengatasi inflsi dan misi dari otoritas fiscal untuk menyakinkan rakyatnya untuk mengurangi pengangguran. Diasumsikan the socially optimal level dari $y^{*}, \pi^{*}, D^{*}, r^{*}$ dianggap sama untuk kedua otoritas kebijakan. Oleh karena itu kekuatan untuk mengendalikan perekonomian dimodelkan sebagai berikut :

$$
\begin{aligned}
& y-y^{*}=\gamma_{D}\left(D-D^{*}\right)-\gamma_{r}\left(r-r^{*}\right)+\gamma_{0} \\
& \pi-\pi^{*}=\lambda_{y}\left(y-y^{*}\right)-\lambda_{0}
\end{aligned}
$$

Persamaan (II.3) menggambarkan fungsi permintaan agregat, sedangkan persamaan (II.4) menggambarkan penawaran agregat atau menggambarkan Philips curve. Dimana, $y-y^{*}$ merupakan selisih tingkat output ( output gap), $\pi-\pi^{*}$ menggambarkan penyimpangan inflasi dari tingkat optimalnya. $\gamma_{D}-\gamma_{r}$ merepresentasikan elastisitas selisih output (output gap) dengan deficit fiscal dan tingkat suku bunga riil, $\lambda_{y}$ menggambarkan elastisitas tingkat inflasi dengan output gap. Sedangkan shock untuk penawaran dan permintaan agregat dinotasikan dengan, $\gamma_{0}, \lambda_{0}$ untuk kemudahan penghitungan diasumsikan $D^{*}, r^{*}=0$.

Solusi untuk kasus shock penawaran agregat yang bernilai positif $\left(\boldsymbol{\lambda}_{0}>0\right)$ sebenarnya sangat sederhana. Shock penawaran positif akan menyebabkan tingkat inflasi lebih rendah dari $\lambda^{*}$ sedangkan output melebihi $y^{*}$, pada kasus kedua otoritas menerapkan kebijakan longgar, dan tidak ada respon kebijakan. Sebaliknya shock penawaran negative akan menurunkan output dan meningkatkan inflasi, sehingga mendesak kedua otoritas kebijakan untuk bereaksi.

Berdasarkan shock penawaran negative, maka fungsi kerugian (loss function) untuk persamaan (II.1) dan persamaan (II.2) dapat dituliskan sebagai berikut :

$$
\begin{aligned}
& U^{F}=-\alpha^{M}\left(y-y^{*}\right)^{2}-\beta^{F}\left(\pi-\pi^{*}\right)^{2}-\delta\left(D-D^{*}\right)^{2} \\
& U^{M}=-\alpha^{M}\left(y-y^{*}\right)^{2}-\beta^{M}\left(\pi-\pi^{*}\right)^{2}-\tau\left(r-r^{*}\right)^{2}
\end{aligned}
$$

Dari penyederhanaan persamaan utilitas pada kedua otoritas terlihat bahwa pada tingkat keseimbangan ( level equilibrium ) nilai $y<y^{*}$ dan $\pi>\pi^{*}$. 
Dalam kondisi optimal dari masing-masing kebijakan (a single economic authority), pertama-tama ditentukan level optimal dari $D$ dan $r$ pada dua kasus dimana otoritas moneter dan fiskal mampu menentukan instrument tersebut dengan sendirinya. Selanjutnya bandingkan situasi dimana setiap otoritas kebijakan menentukan instrument mereka sendiri pada saat kurangnya koordinasi kebijakan dengan scenario alternative seperti, otoritas tunggal ekonomi mengatur kebijakan moneter dan fiscal atau kedua otoritas bekerja untuk mengkoordinasikan kebijakan.

Ketika otoriatas kebijakan fiscal juga berkeinginan untuk menentukan tingkat suku bunga, maka first-order condition nya adalah sebagai berikut :

$$
\begin{aligned}
& \frac{\partial U^{F}}{\partial D}=-2 \alpha^{F}\left(y-y^{*}\right) \gamma_{D}-2 \beta^{F}\left(\pi-\pi^{*}\right) \lambda_{y} \gamma_{D}-2 \delta D=0 \\
& \frac{\partial U^{F}}{\partial r}=2 \alpha^{F}\left(y-y^{*}\right) \gamma_{r}+2 \beta^{F}\left(\pi-\pi^{*}\right) \lambda_{y} \gamma_{r}=0
\end{aligned}
$$

Dari persamaan (II.7) dan mensubsitusinya ke dalam persamaan (II.3) dan (II.4), maka akan diperoleh fungsi reaksi fiscal (Fiscal reaction function / FRnFn) sebagai berikut :

$$
D=\left[\frac{1}{1+\frac{\delta}{\gamma_{D}^{2}\left(\alpha^{F}+\beta^{F} \lambda_{y}^{2}\right)}}\right] \frac{\gamma_{r}}{\gamma_{D}}+\left[\frac{\lambda_{y} \lambda_{0}}{\frac{\delta}{\beta^{F} \gamma_{D}}+\gamma_{D}\left(\alpha^{F} / \beta^{F}+\lambda_{y}^{2}\right)}\right]
$$

Dari persamaan (II.8) kita akan mendapatkan fungsi maksimisasi silang fiscal (fiscal crossmaximization function ( FrMX), yang merupakan optimisasi otoritas fiscal dengan instrumen moneter (tingkat suku bunga), seperti berikut ini :

$$
D=\frac{\gamma_{r}}{\gamma_{D}} r+\left[\frac{\lambda_{y} \lambda_{0}}{\gamma_{D}\left(\alpha^{F} / \alpha^{F}+\lambda_{y}^{2}\right)}\right]
$$

Titik potong antara FRnFn dengan CrMX akan menghasilkan pasangan optimal dari instrumen kebijakan fiscal $\left(D^{F}, r^{F}\right)$ atau lebih dikenal dengan nama titik kebahagian (bliss point).

Berdasarkan analogi diatas, bliss point untuk otoritas moneter dapat dihitung. Ketika bank sentral menentukan $D$ dan $r$, first-order condition dapat diturunkan dengan memaksimisasi fungsi utilitas dari bank sentral (6) berdasarkan kedua instrument kebijakn. Sehingga pada akhirnya kita akan mendapatkan fungsi reaksi moneter (The Monetary Reaction Function/MRnFn) sebagai berikut: 


$$
\frac{\partial U^{M}}{\partial r}=0 \Rightarrow D=\left[1+\frac{\tau}{\gamma_{r}^{2}\left(\alpha^{M}+\beta^{M} \lambda_{y}^{2}\right)}\right] \frac{\gamma_{r}}{\gamma_{D}} r+\left[\frac{\lambda_{y} \lambda_{0}}{\gamma_{D}\left(\alpha^{M} / \beta^{M}+\lambda_{y}^{N}\right)}\right],
$$

Sedangkan fungsi maksimisasi silang moneter (The Monetary Cross-Maximization Function / MCrMx) ditunjukan sebagai berikut :

$$
\frac{\partial U^{M}}{\partial D}=0 \Rightarrow D=\frac{\gamma_{r}}{\gamma_{D}} r+\left[\frac{\lambda_{y} \lambda_{0}}{\lambda_{D}\left(\alpha^{M} / \beta^{M}+\lambda_{y}^{2}\right)}\right]
$$

Bliss point dari otoritas moneter $\left(D^{M}, r^{M}\right)$ didapatkan dengan cara yang sama dengan bliss point otoritas fiscal. Bliss point dari otoritas moneter didapat dari perpotongan antara garis MRnFn dengan garis MCrMx.

Dari perhitungan yang telah dilakukan oleh penulis ternyata bliss point otoritas moneter jauh lebih rendah daripada bliss point otoritas fiscal, hal ini dikarenakan preferensi relative untuk inflasi dan tingkat output dari otoritas fiscal lebih tinggi nilainya daripada otoritas moneter $\left(\alpha^{F} / \beta^{F}\right)>\left(\alpha^{M} / \beta^{M}\right)$.

Nash Equilibrium berlaku ketika kedua otoritas kebijakn memutuskan strategi mereka bersifat simultan dan tanpa ada koordinasi kebijakan. Solusi dari Nash didapat ketika setiap otoritas memaksimisasi fungsi utilotasnya dengan memperhatikan instrument kebijkan mereka sendiri. Persamaan (II.7) dan (II.11) menggambarkan first order condition dari solusi Nash. Sedangkan persamaan (II.9) merepresentasikan fungsi reaksi dari otoritas fiskal dan persamaan (II.11) fungsi reaksi dari otoritas moneter.

Solusi dari Nash diperoleh dari titik potong antara MRnFn dengan FRnFn, dengan melewati beberapa perhitungan aljabar, solusi dari Nash Equilibrium $\left(D^{N}, r^{N}\right)$ diperoleh sebagai berikut :

$$
\begin{aligned}
& D^{N}=\frac{-\gamma_{r}^{2} \lambda_{y}\left(\alpha^{F} \beta^{M}-\alpha^{M} \beta^{F}\right) \lambda_{0}+\tau \beta^{F} \lambda_{y} \lambda_{0}}{\gamma_{r}^{2} \delta / \gamma_{D}\left(\alpha^{M}+\beta^{M} \lambda_{y}^{2}\right)+\tau \delta / \gamma_{D}+\gamma_{D} \tau\left(\alpha^{F}+\beta^{F} \lambda_{y}^{2}\right)} \\
& r^{N}=\frac{-\gamma_{D}^{2} \lambda_{y}\left(\alpha^{F} \beta^{M}-\alpha^{M} \beta^{F}\right) \lambda_{0}+\tau \beta^{F} \lambda_{y} \lambda_{0}}{\gamma_{r} \delta\left(\alpha^{M}+\beta^{M} \lambda_{y}^{2}\right)+\tau \delta / \gamma_{r}+\gamma_{D}^{2} \tau / \gamma_{r}\left(\alpha^{F}+\beta^{F} \lambda_{y}^{2}\right)}
\end{aligned}
$$

$D^{N}$ akan bernilai negative jika perbedaan preferensi diantara otoritas fiscal dan moneter kecil dengan memperhatikan kerugian Bank Sentral akibat adanya perubahan tingkat suku bunga dari target yang sudah ditentukan. Hal ini dapat berimplikasi buruk pada perekonomian, karena 
kehadiran shock penawaran negative akan menyebabkan independensi Bank Sentral dapat menghasilkan inflasi yang lebih tinggi daripada fiskal bliss point. Oleh karena itu, diperlukan suatu kondisi khusus sehingga menyebabkan Nash Equilibrium selalu memenuhi deficit yang lebih besar dan tingkat suku bunga yang lebih tinggi daripada solusi otoritas ekonomi tunggal (a single economic authority). Kondisi tersebut adalah sebagai berikut :

$$
\alpha^{F} \beta^{M}-\alpha^{M} \beta^{F}>\tau \frac{\beta^{F}}{\gamma_{r}^{2}}
$$

Dimana nilai inflasi yang rendah yang diakibatkan oleh bank sentral lebih besar daripada nilai inflasi yang diakibatkan oleh otoritas fiscal dan lebih besar daripada tingkat suku bunga dalam jangka panjang.

Jika perbedaan preferensi diantara dua otoritas kebijakan semakin melebar ( atau dengan kata lain perbedaan diantara $\alpha^{F} / \beta^{F}$ dengan $\alpha^{M} / \beta^{M}$ semakin meningkat ), akan menyebabkan bliss point dari Nash Equilibrium semakin ke kanan atas, atau terjadinya peningkatan level pada kedua instrumen ( rendahnya inflasi dan rendahnya permintaan agregat).

Dengan mensubstitusi hasil $D^{N}$ dan $r^{N}$ ke persamaan (II.3) dan persamaan (II.4), akan terlihat bahwa equilibrium tingkat output lebih rendah daripada $y^{*}$ sedangkan tingkat inflasi lebih tinggi daripada $\pi^{*}$, atau dengan kata lain solusi Nash Equilibrium berada dalam range $y<$ $y^{*}$ dan $\pi>\pi^{*}$.

Kesimpulan yang dapat diambil dari model Nash Game adalah sebagai berikut : tidak adanya koordinasi kebijakan diantara otoritas fiscal dan moneter untuk bereaksi terhadap shock penawaran negatif (dimana setiap otoritas kebijakan menetukan kedua instrument kebijakan itu sendiri) akan menghasilkan defisit fiscal yang tinggi dan tingkat suku bunga yang tinggi pula. Ketika terjadi peningkatan perbedaan preferensi diantara otoritas fiskal, menyebabkan deficit fiscal semakin membesar dan tingkat suku bunga semakin tinggi.

\section{Koordinasi Kebijakan Moneter dan Fiskal di Indonesia}

Keberhasilan kebijakan-kebijakan ekonomi makro, seperti kebijakan moneter, fiskal, perdagangan dan Industri, dalam mencapai tujuan akhir tidak dapat berdiri sendiri. Kebijakan tanpa memperhatikan kebijakan di sektor lain akan tidak optimal dan bahkan dapat berdampak negatif terhadap perekonomian secara keseluruhan. Sebagai contoh kebijakan moneter yang hanya mengutamakan kestabilan harga atau inflasi yang rendah dapat mengganggu tujuan kebijakan fiskal karena dapat menghambat pertumbuhan ekonomi dan meningkatkan pengangguran. Dengan demikian peranan koordinasi menjadi penting dalam mengoptimalkan 
pencapaian tujuan akhir daripada kebijakan ekonomi makro, berupa meningkatkan kesejahteraan rakyat.

Sementara itu, kebijakan fiskal yang terlalu longgar sebagaimana dijelaskan pada bagian sebelumnya dapat mengakibatkan terjadinya inflasi. Sebaliknya, kebijakan fiskal yang terlalu ketat, seperti penarikan pajak yang berlebihan di masyarakat dapat menurunkan konsumsi² atau mengurangi alokasi dana yang produktif sehingga dapat menekan pertumbuhan ekonomi.

\section{III.1. Aspek Hukum Koordinasi Kebijakan Moneter dan Kebijakan Fiskal}

Secara hukum, koordinasi antara kebijakan moneter dan fiskal di Indonesia mengalami masa pasang surut sejalan dengan ketentuan atau perundangan yang berlaku. Pada masa Undang Undang No. 13 tahun 1968 tentang Bank Indonesia, Bank Indonesia merupakan anggota dewan moneter yang ketuanya adalah Menteri Keuangan dan merupakan perwakilan Pemerintah. Secara hukum, dengan kondisi tersebut tidak ada permasalahan koordinasi antara Pemerintah dan BI karena BI merupakan mitra kerja di dalam dewan moneter. Namun karena BI termasuk bagian dari Pemerintah, maka tidak terdapat lagi sistem pengendalian intern yang dapat mencegah Pemerintah untuk membiayai defisitnya berasal dari BI. Pada periode tersebut, tidak sedikit BI memberikan kredit kepada Pemerintah, lembaga pemerintah dan bank, seperti kredit kepada BULOG dan kredit likuiditas. Pemberian kredit tersebut merupakan penciptaan uang baru oleh $\mathrm{BI}$ yang bersifat inflationary sehingga dapat mengganggu stabilitas makroekonomi.

Selanjutnya, dengan Undang Undang No. 23 tahun 1999 sebagaimana diubah dengan Undang Undang No. 3 tahun 2004, Bank Indonesia merupakan lembaga yang independent dalam melaksanakan tugas-tugasnya. Walaupun independen, dalam undang undang tersebut juga disebutkan beberapa fasal koordinasi kebijakan fiskal dan moneter, seperti pasal 55, ayat 1 menyebutkan bahwa dalam hal Pemerintah menerbitkan surat-surat utang negara, Pemerintah wajib terlebih dahulu berkonsultasi dengan Bank Indonesia. Dari sisi pandangan kebijakan moneter, pasal ini dapat diterjemahkan pembiayaan fiskal defisit harus memperhatikan tujuan akhir kebijakan moneter berupa stabilitas rupiah. Dalam ayat 4 pasal yang sama disebutkan BI dilarang membeli surat-surat utang negara di pasar primer. Pasal tersebut merupakan suatu upaya pencegahan agar pemerintah tidak membiayai fiskal defisit secara langsung dari bank sentral yang dapat berdampak terhadap peningkatan laju inflasi.

2 Ricardian equivalence mengemukakan bahwa konsumsi tidak akan berubah karena pada masa yang akan datang masyarakat berekspektasi akan terjadi pemotongan pajak sehingga konsumsi tidak berubah. 
Berdasarkan Undang Undang Bank Indonesia terlihat koordinasi kebijakan moneter dan fiskal telah diatur cukup baik, seperti terdapat pembatasan pembiayaan fiskal defisit yang berasal dari Bank Indonesia. Selain itu, dalam penetapan inflasi sebagai tujuan akhir dari BI, Pemerintah berkoordinasi dengan $\mathrm{BI}$.

\section{III.2. Fakta Empiris Koordinasi kebijakan Moneter dan Fiskal}

Pada bagian sebelumnya diuraikan hubungan antara kebijakan moneter dan fiskal dari sisi aspek hukum. Pada bagian berikutnya akan diuraikan data-data empiris mengenai hubungan antara kebijakan moneter dan kebijakan fiskal. Sebelum masuk lebih jauh terhadap topik tersebut, secara singkat akan diuraikan mengenai masing-masing tujuan kebijakan moneter dan fiskal di Indonesia.

Seperti di negara-negara lainnya, tujuan kebijakan fiskal di Indonesia khususnya sejak PELITA I lebih ditekankan kepada mendorong pertumbuhan ekonomi dan pemerataan hasil pembangunan dengan jalan memperluas kesempatan kerja. Seiring dengan meningkatnya pinjaman luar negeri, kebijakan fiskal juga diarahkan pada penyelesaian utang luar negeri dan dalam negeri untuk mecapai kondisi fiskal yang sutainable.

Sementara itu, tujuan kebijakan moneter BI berdasarkan UU No. 23/1999 sebagaimana telah diubah dengan UU No. 3/2004 adalah mengatur, menjaga, dan memelihara kestabilan nilai rupiah. Kestabilan rupiah tersebut mencakup inflasi dan nilai tukar rupiah. Pada masa sebelum UU tersebut dikeluarkan, tujuan BI selain menjaga kestabilan rupiah juga mencakup mendorong kelancaran produksi dan pembangunan serta memperluas kesempatan kerja guna meningkatkan taraf hidup rakyat.

Pemberian kewenangan kepada BI hanya mestabilkan nilai rupiah agar BI lebih fokus dalam mencapai tujuannya dan sekaligus sebagai mengamankan atau mengendalikan kebijakan yang dapat membahayakan inflasi. Misalnya, kebijakan pemerintah untuk mendorong pertumbuhan ekonomi dalam jangka pendek melalui pembiayaan defisit dapat membahayakan inflasi dan stabilitas makro, dapat dinetralisir atau dikendalikan melalui kebijakan moneter yang ketat. Dengan demikian, terdapat kemungkinan terjadinya perbedaan penekanan pada kedua kebijakan tersebut, yaitu kebijakan moneter lebih menekankan kepada inflasi, sementara kebijakan fiskal lebih menekankan pertumbuhan ekonomi dan kesempatan kerja. Dengan adanya perbedaan penekanan tujuan tersebut maka jika tidak terdapat koordinasi maka dapat mengganggu stabilitas makroekonomi.

Setelah membahas mengenai tujuan kebijakan moneter dan fiskal di Indonesia serta terdapatnya perbedaan penekanan tujuan dari masing-masing kebijakan, pada bagian berikutnya 
akan dibahas fakta empiris koordinasi kebijakan moneter dan fiskal di Indonesia. Sebagaimana diketahui secara teoritis pertambahan uang primer $^{3}$ (base money) akan sama dengan pertambahan net domestic assets (NDA) dan net foreign assets (NFA) atau net international reserve (NIR). Secara matematis perhitungan tersebut dapat diformulasikan sebagai berikut:

$$
\Delta M_{0}=\Delta N D A+\Delta N I R
$$

$\Delta M_{0}$ adalah pertambahan uang primer, terdiri dari pertambahan tagihan bersih kepada pemerintah (NCG), pertambahan tagihan bersih kepada bank, perorangan dan perusahaan (NCBS) dan pertambahan faktor-faktor lainnya (NOI). Setiap pengeluaran pemerintah akan dicatat di NCG sehingga jika tidak terjadi pengeluaran NCG maka uang primer (M0) akan meningkat.

Berdasarkan data empiris seperti terlihat di grafik II.1, Pertumbuhan Net Claim to Government (NCG) dengan pertumbuhan Base Money pada tahun 1981 sampai 2004 mempunyai kecenderungan untuk berhubungan positif, setiap terjadi ekspansi NCG, maka akan menyebabkan terjadinya peningkatan pertumbuhan uang beredar. Hal ini dapat dilihat dalam plot grafik II.1, pada saat terjadi ekspansi NCG pada tahun 1983 sebesar $31.81 \%$ daripada tahun sebelumnya, menyebabkan pertumbuhan uang primer meningkat menjadi 25 $\%$ daripada tahun sebelumnya yang hanya tumbuh sebesar $4 \%$.

Pada tahun 1992 pertumbuhan NCG sebesar 27.45 \% dibandingkan tahun sebelumnya, peningkatan NCG ini direspon positif oleh peningkatan uang primer pada saat itu yang pertumbuhannya meningkat sampai 31 \% dibandingkan tahun sebelumnya yang hanya

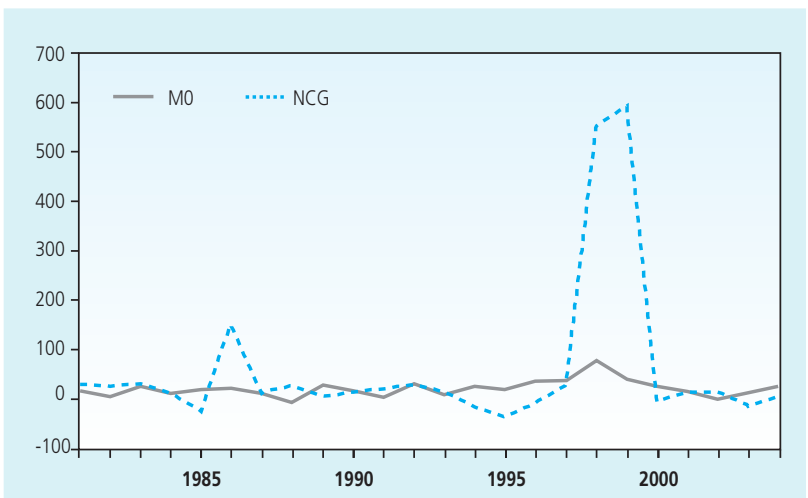

Grafik II.1. Pertumbuhan Tahunan NCG dengan Uang Primer

3 Uang primer adalah kewajiban moneter dari otoritas moneter (BI) yang terdiri dari uang kartal di masyarakat dan bank, giro bank di BI dan kewajiban sektor swasta lainnya. 
tumbuh pada tingkat $3 \%$. Respon positif terbesar uang primer terhadap perubahan NCG terjadi pada saat krisis ekonomi pada tahun 1998, pada saat itu pertumbuhan NCG meningkat menjadi $552 \%$ dibanding tahun sebelumnya yang sebesar $28 \%$, pertumbuhan NCG yang sangat besar tersebut menyebabkan peningkatan pada pertumbuhan uang primer yang meningkat menjadi $77 \%$ dibandingkan pertumbuhan tahun sebelumnya yang berkisar pada tingkat $38 \%$.

Secara teoritis, melalui suatu proses penciptaan uang maka uang primer akan ditransformasikan ke dalam uang beredar dalam artian sempit (M1) dan dalam artian luas (M2). Pada saat pemerintah meningkatkan pengeluaran seperti tercermin dari peningkatan NCG, maka menyebabkan terjadinya peningkatan uang primer. Peningkatan uang primer akan berdampak pada peningkatan uang beredar ( M1/M2 ) seperti terlihat di grafik II.2.

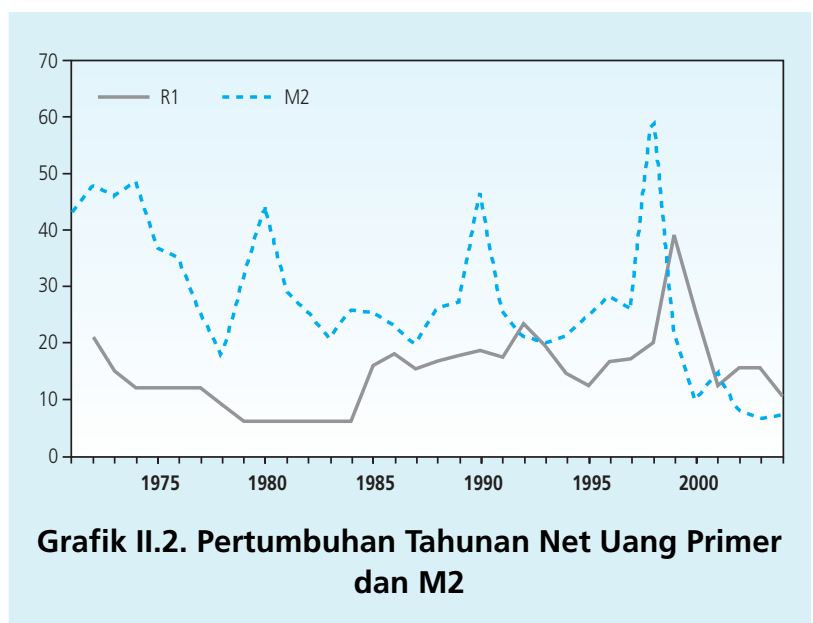

Sementara itu, berdasarkan grafik II.3 terlihat bahwa hubungan antara uang beredar (M1/M2) dan inflasi adalah positif. Pada saat pertumbuhan uang beredar meningkat sampai 49 \% pada tahun 1974, ternyata diikuti oleh peningkatan laju inflasi pada saat itu, yaitu sebesar 40\%. Dampak positif pertumbuhan uang beredar juga dapat dilihat pada tahun 1980 dan tahun 1998, pada tahun-tahun tersebut pertumbuhan uang beredar mencapai 44 \% dan 66 \% sedangkan laju inflasi juga mengalami peningkatan sampai pada tingkat $18 \%$ dan $58 \%$.

Hubungan langsung antara pengeluaran pemerintah (APBN) dan inflasi juga menunjukkan hubungan yang positif (Grafik II.4). Pada saat pemerintah menetapkan kebijakan fiskal ekspansif maka akan menyebabkan peningkatan laju inflasi. Hal ini dapat dimengerti karena peningkatan pengeluaran pemerintah akan meningkatkan agregat demand sehingga menyebabkan terjadinya 


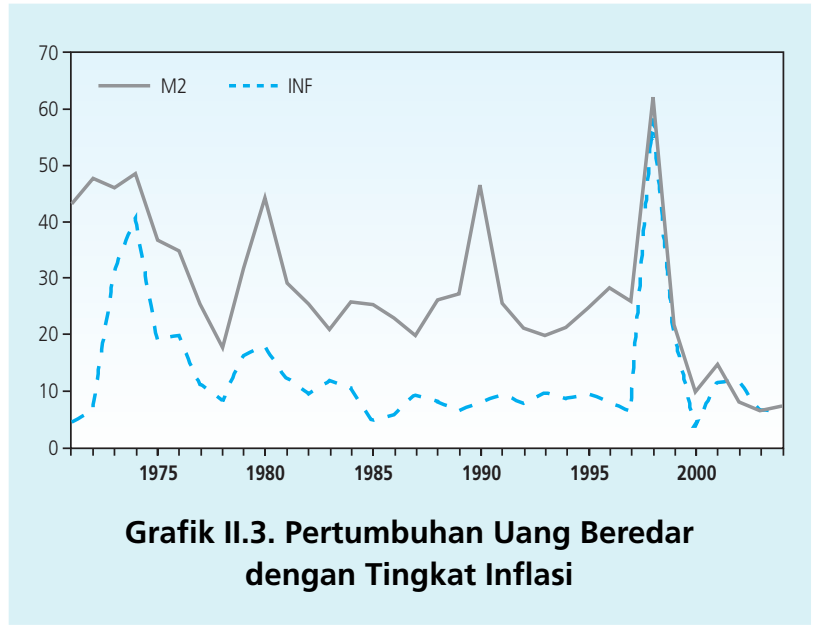

peningkatan harga-harga secara umum (inflasi). Disaat pemerintah meningkatkan pengeluarannya pada tahun 1974 sampai 68,35\%, laju inflasi pada tahun tersebut juga meningkat menjadi $40 \%$. Peningkatan laju inflasi yang diakibatkan oleh peningkatan pengeluaran pemerintah juga terjadi pada tahun 1980, pada saat itu pertumbuhan pengeluaran pemerintah mencapai $48.6 \%$ sedangkan laju inflasi mencapai $18 \%$.

Dampak positif pertumbuhan pengeluaran pemerintah terhadap laju inflasi dapat dilihat juga tahun 1998 dan pada tahun 2000. Pada tahun 1998, ketika pertumbuhan pengeluaran pemerintah meningkat sampai $54 \%$, ternyata diikuti peningkatan laju inflasi sebesar $58 \%$, sedangkan pada saat pertumbuhan pengeluaran pemerintah menurun sampai tingkat - $2 \%$ pada tahun 2000, laju inflasi juga menurun sampai tingkat $3.7 \%$.

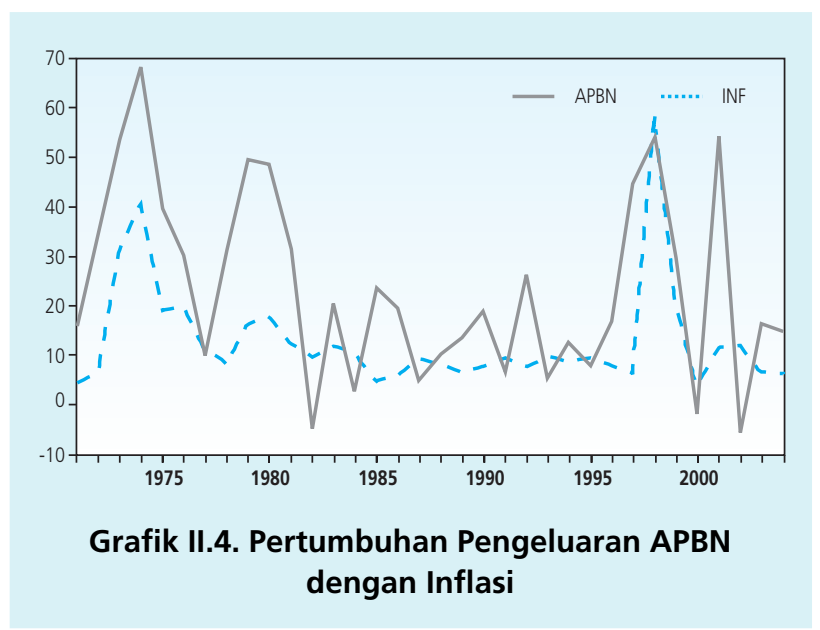


Hubungan pengeluaran pemerintah dengan pertumbuhan ekonomi juga menunjukkan hubungan posistif. Dari grafik II.5 dapat dilihat bahwa pengeluaran APBN cenderung berdampak positif terhadap pertumbuhan ekonomi. Dampak positif paling nyata terlihat pada saat pengeluaran pemerintah meningkat sebesar 12.5 \% pada tahun 1994 daripada tahun sebelumnya yang hanya sebesar $5.3 \%$, pertumbuhan ekonomi juga meningkat sebesar $7.5 \%$ daripada tahun sebelumnya yang hanya 6.5 \%. Pada saat krisis tahun 1998 hubungan tersebut tidak stabil, ketika pengeluaran pemerintah meningkat sampai $54.2 \%$ pada tahun 1998 , ternyata pertumbuhan ekonomi pada tahun tersebut malah mengalami penurunan sampai tingkat $13 \%$.

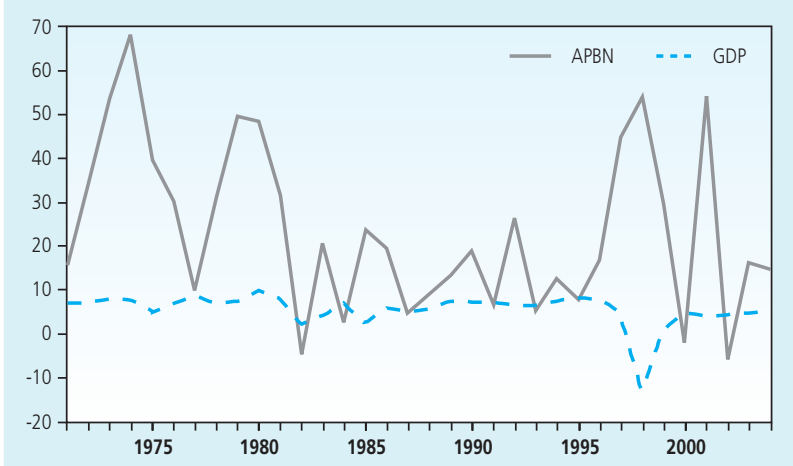

Grafik II.5. Pertumbuhan Pengeluaran APBN dengan Pertumbuhan Ekonomi

Sementara itu, hubungan kebijakan moneter dengan pertumbuhan ekonomi dapat dilihat dari perkembangan suku bunga dengan pertumbuhan ekonomi. Pengaruh negatif Suku bunga deposito berjangka 3 bulan terhadap pertumbuhan ekonomi dapat dilihat grafik II.6. Dalam

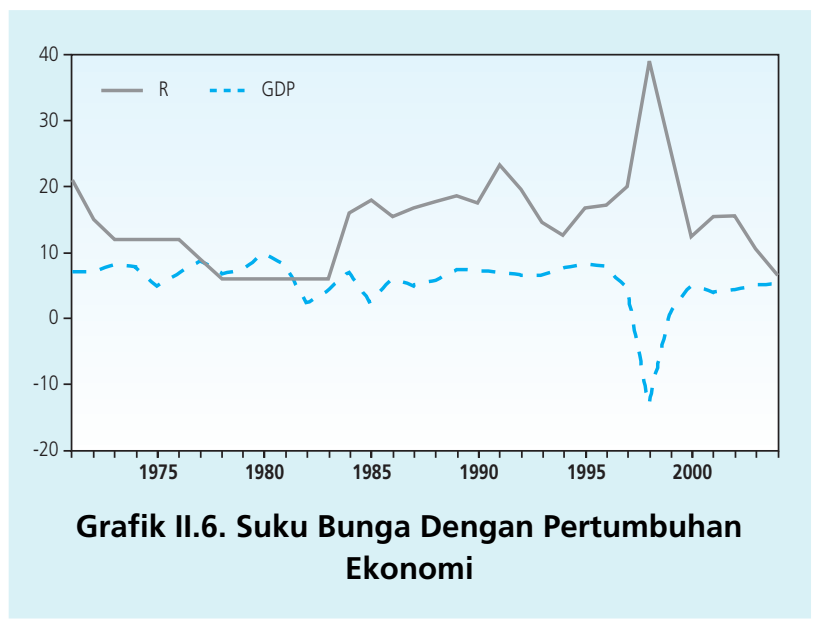


plot grafik II. 6 terlihat bahwa pada saat suku bunga berjangka 3 bulan meningkat, maka menyebabkan pertumbuhan ekonomi pengalami kontraksi. Pada tahun 1980, saat suku bunga deposito diturunkan pada tingkat $6 \%$, maka pertumbuhan ekonomi pada saat itu meningkat sampai $9.8 \%$. Sedangkan pada saat bunga deposito ditingkatkan menjadi $18 \%$ pada tahun 1985, membuat pertumbuhan ekonomi mengalami penurunan.

\section{Data dan Model}

\section{IV.1. Data}

Data yang digunakan data mulai tahun 1970 sampai dengan tahun 2004. Data pengeluaran APBN sebagai proxy kebijakan fiskal, suku bunga sebagai proxy kebijakan moneter. Sementara itu, sebagai tujuan akhir dari masing-masing kebijakan digunakan data inflasi dan pertumbuhan ekonomi. Kebijakan fiskal diasumsikan lebih menitikberatkan pertumbuhan ekonomi, sementara kebijakan moneter lebih ditekankan kepada laju inflasi yang rendah.

\section{IV.2. Model}

Model teoritis didasarkan atas metode dynamic game antara kebijakan moneter dan fiskal yang dapat dimodelkan sebagai berikut (Petit, 1989):

$$
x=A x(t)+B_{1} u_{1}(t)+B_{2} u_{2}(t)+C z(t)
$$

dimana $\mathrm{x}(\mathrm{t})$ adalah vektor dari state variabel, $\mathrm{z}(\mathrm{t})$ adalah variabel exogenous yang tidak terkontrol $u_{1}(t)$, adalah variabel yang dapat dikontrol oleh pemain 1 dan $u_{2}(t)$ adalah variabel yang dapat dikontrol oleh pemain 2, dan $A, B 1, B 2$ dan $C$ adalah matriks konstan dari dimensi yang dipersyaratkan.

Sementara itu, pembuat kebijakan/pemain akan memilih optimal strategi dengan meminimalkan fungsi biayanya pada periode $t \in\left[t_{0}, t_{f}\right]$, misalnya dalam bentuk quadratic sebagai berikut:

$$
\begin{aligned}
& \left.J_{i}=\int_{t 0}^{t} f\left[x(t)-\hat{x}_{i}(t)\right]^{T} Q_{i}\left[x(t)-\hat{x}_{i}(t)\right]+\left[u_{i}(t)-\hat{u}_{i}(t)\right]^{T} R_{i i}\left[u_{i}(t)-\hat{u}_{i}(t)\right]\right\} d t \\
& \mathrm{i}=1,2
\end{aligned}
$$

dimana $Q_{i}$ merepresentasikan tujuan tertimbang dari pemain $i$ untuk berdeviasi dari path yang ideal $\left(Q_{i} \geq 0\right)$ dan matriks $R_{i i}$ merepresentasikan tujuan tertimbang dari pemain I terhadap deviasi variabel yang ditetapkan sendiri dengan path yang ideal $\left(R_{i i}>0\right)$. 
Dari model teoritis tersebut dapat dibangun fungsi tujuan dari masing-masing pembuat kebijakan/pemain.

Fungsi tujuan dari pemerintah (kebijakan fiskal) dapat dimodelkan sebagai berikut:

$J_{1}=\int_{1970}^{2002}\left\{w_{Y 1} \log [Y(t)-\log \hat{Y}(t)]^{2}+w_{P 1}[\log P(t)-\log \hat{P}(t)]^{2}+w_{G 1}[\log G(t)-\log \hat{G}(t)]^{2}\right\} d t$,

Sementara itu, fungsi tujuan dari kebijakan moneter dapat diformulasikan sebagai berikut:

$J_{2}=\int_{1970}^{2002}\left\{w_{P 2} \log [P(t)-\log \hat{P}(t)]^{2}+w_{R 2}[\log Y(t)-\log \hat{Y}(t)]^{2}+w_{m 2}[\log i(t)-\log \hat{i}(t)]^{2}\right\} d t$,

Dimana $Y$ adalah produk domestik bruto/PDB (harga konstan), adalah PDB yang ideal/optimal, $P$ adalah tingkat harga, $i$ adalah suku bunga dan tanda ${ }^{\wedge}$ adalah variabel ideal yang diharapkan yang didapat dari perhitungan data empiris.

\section{Hasil Pengujian Empiris Koordinasi Kebijakan Moneter dan Fiskal di Indonesia}

\section{V.1. Hasil Empiris}

Berdasarkan kajian empiris di dapat path yang ideal dari masing-masing vaiabel di atas sebagai berikut:

$$
\begin{aligned}
& \log \hat{Y}(t)=\log Y\left(t_{0}\right)+0.05 t \\
& \log \hat{P}(t)=\log P\left(t_{0}\right)+0.11 t \\
& \log \hat{G}(t)=\log G\left(t_{0}\right)+0.07 t \\
& r=2 \%
\end{aligned}
$$

Sementara bobot dari masing-masing variabel dari kebijakan adalah sebagai berikut:

$$
\begin{aligned}
& w_{y 1}=2, w_{p 1}=1, w_{g 1}=1 \\
& w_{p 2}=2, w_{y 2}=1, w_{i 2}=1 \\
& t_{0}=1970
\end{aligned}
$$

Bobot tersebut menunjukkan bahwa kebijakan fiskal lebih menekankan kepada pertumbuhan ekonomi dibandingkan dengan laju inflasi, seperti tercermin dari bobot untuk pertumbuhan ekonomi sebesar 2 yang lebih besar dibandingkan dengan bobot harga yang hanya sebesar 1 . Sebaliknya, kebijakan moneter lebih menekankan inflasi dibandingkan dengan pertumbuha ekonomi, seperti tercermin dari bobot inflasi sebesar 2 dibandingkan dengan pertumbuhan ekonomi sebesar 1. 
Hasil dari lost function terhadap perekonomian jika BI dan pemerintah tidak bekerjasama berdasarkan teori permainan adalah sebagai berikut:

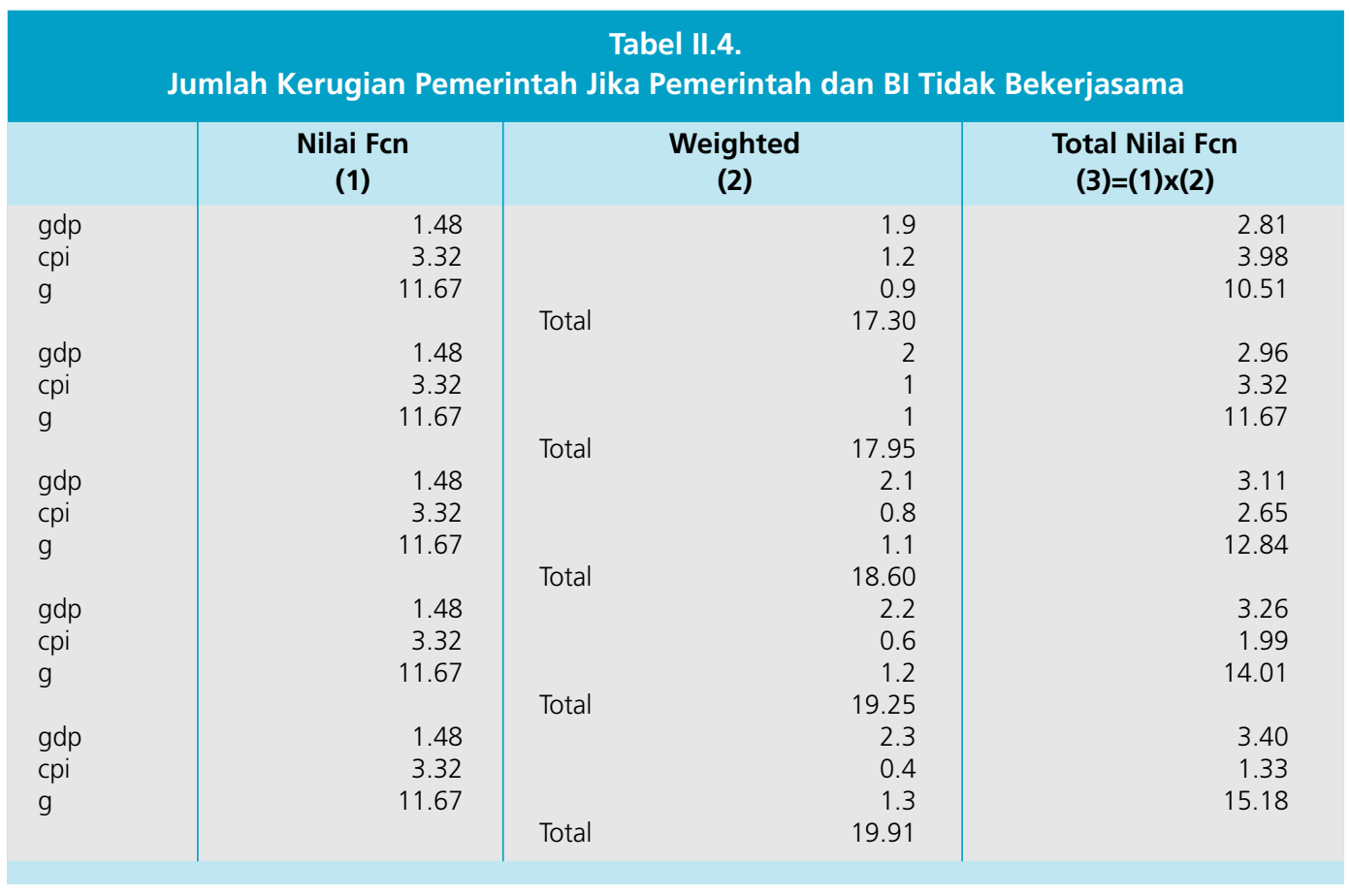

Berdasarkan hasil perhitungan Tabel II.4 di atas terlihat, jumlah kerugian pemerintah terhadap ekonomi jika pemerintah (kebijakan fiskal) dan BI (kebijakan moneter) tidak bekerjasama adalah sebesar 17,95. Selanjutnya, jika pemerintah berkeinginan meningkatkan pertumbuhan ekonomi lebih besar (seperti tercermin dari bobot GDP dan G yang lebih besar) maka jumlah kerugian bagi perekonomian menjadi lebih besar, yaitu sebesar 18,60. Sebaliknya, jika pertumbuhan ekonomi lebih kecil atau inflasi lebih rendah maka jumlah kerugian bagi ekonomi yang berasal dari pemerintah menjadi lebih kecil, yaitu sebesar 17,30. Dengan mengacu pada hasil empiris tersebut, maka setiap upaya pemerintah untuk meningkatkan pertumbuhan ekonomi dalam jangka pendek mengakibatkan social welfare menjadi berkurang.

Total kerugian ekonomi yang berasal dari BI jika pemerintah dan BI tidak bekerjasama adalah sebesar 16,36. Hasil empiris juga menunjukkan bahwa jika BI terlalu memperhatikan inflasi dan mengabaikan pertumbuhan ekonomi dapat mengakibatkan terjadinya total kerugian ekonomi yang lebih besar. Kondisi tersebut tercermin dari tabel II.5 yang menunjukkan bahwa social lost ekonomi lebih besar $(17,22)$ jika BI ingin menurunkan inflasi yang lebih rendah dari path idealnya. Sebaliknya, jika kebijakan moneter lebih diarahkan kepada pertumbuhan ekonomi yang sesuai dengan kapasitasnya maka social lost ekonomi menjadi lebih kecil. 


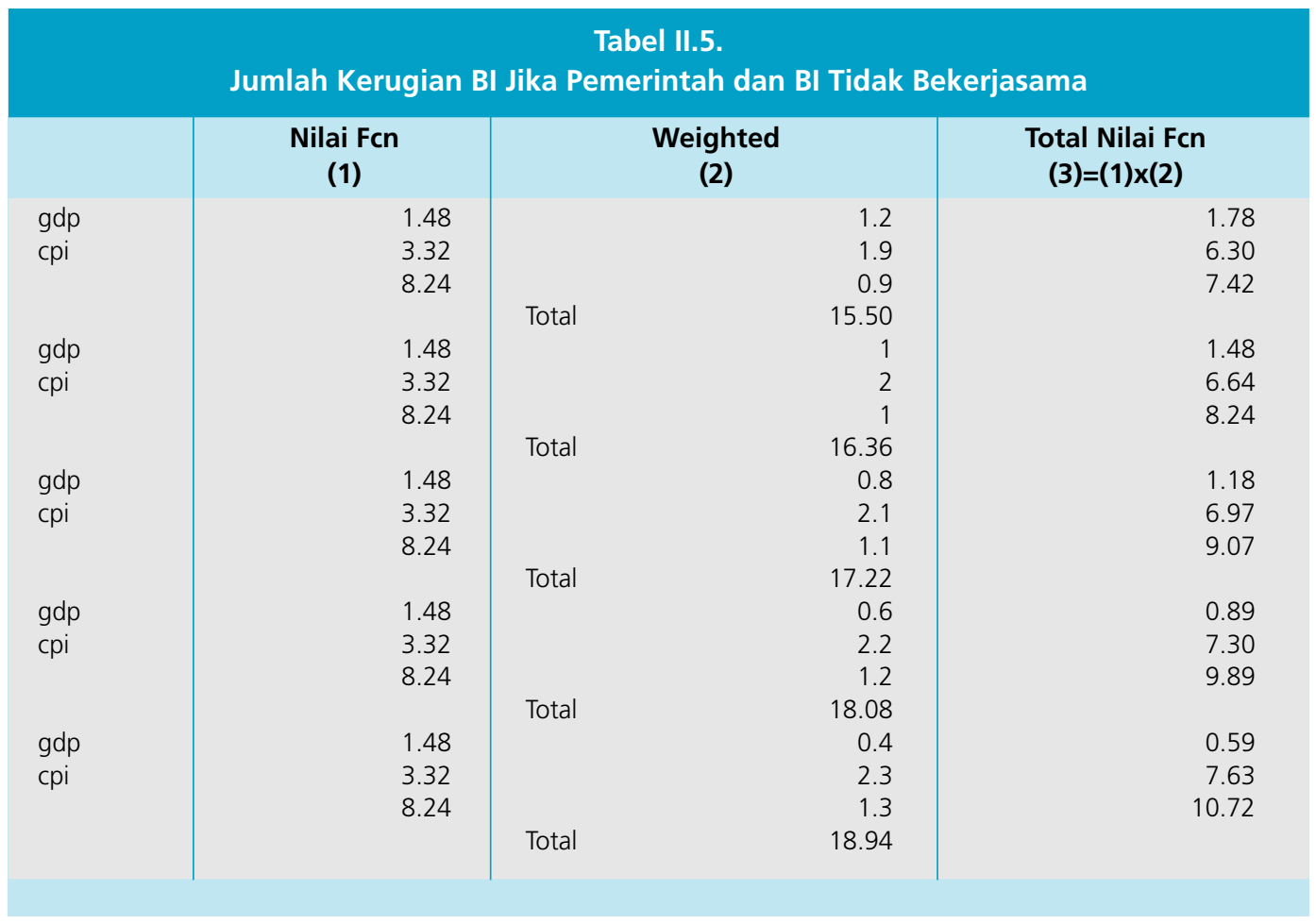

Sementara itu, jika kebijakan moneter (BI) dan kebijakan fiskal (Pemerintah) bekerjasama maka social lost ekonomi menjadi lebih kecil. Tabel II.6 menunjukkan bahwa jika toleransi antar kebijakan sama (koefisien kerjasama sebesar 0,5) maka total social lost bagi perekonomian hanya sebesar 18,24 jauh di bawah total social lost jika tidak bekerjasama, yaitu sebesar 34,31.

Tabel II.6.

Total Kerugian Ekonomi Jika Bekerjasama

\begin{tabular}{|c|c|c|c|}
\hline \multicolumn{3}{|c|}{ Keterangan } & Nilai J \\
\hline a1 & & 0.3 & 5.39 \\
\hline a2 & & 0.7 & 13.26 \\
\hline & Total Nilai & 18.64 & \\
\hline a1 & & 0.4 & 7.44 \\
\hline a2 & & 0.6 & 10.85 \\
\hline & Total Nilai & 18.29 & \\
\hline a1 & & 0.5 & 9.63 \\
\hline a2 & & 0.5 & 8.61 \\
\hline & Total Nilai & 18.24 & \\
\hline a1 & & 0.6 & 10.77 \\
\hline a2 & & 0.4 & 7.96 \\
\hline & Total Nilai & 18.73 & \\
\hline
\end{tabular}




\section{Kesimpulan dan Implikasi Kebijakan}

\section{VI.1. Kesimpulan}

Berdasarkan hasil pembahasan pada bab-bab sebelumnya dapat disimpulkan hal-hal sebagai berikut :

a. Pengalaman empiris di beberapa negara menunjukkan bahwa pembiayaan fiskal defisit yang berasal dari bank dapat mengakibatkan terjadinya peningkatan laju inflasi dan stabilitas makroekonomi.

b. Secara hukum koordinasi kebijakan moneter dan kebijakan fiskal di Indonesia telah berjalan baik.

c. Kebijakan fiskal yang terlalu ekspansif atau mengutamakan pertumbuhan ekonomi di Indonesia dapat mengakibatkan social lost yang lebih besar terhadap perekonomian nasional.

d. Demikian juga halnya dengan kebijakan moneter yang terlalu ketat atau mengutamakan inflasi tanpa memperhatikan pertumbuhan ekonomi dapat mengakibatkan social lost yang lebih besar terhadap perekonomian Indonesia.

e. Koordinasi kebijakan moneter dan kebijakan fiskal memberikan social lost yang lebih kecil terhadap perekonomian dibandingkan jika tidak berkoordinasi.

\section{VI.2. Implikasi Kebijakan}

Implikasi kebijakan dari temuan tersebut adalah diperlukan koordinasi kebijakan moneter dan kebijakan fiskal yang lebih erat lagi, seperti menghindarkan pembuatan kebijakan fiskal yang dapat mengganggu tujuan akhir kebijakan moneter dan sebaliknya. Kerjasama kedua kebijakan diperlukan dalam rangka menghindarkan dampak negatif yang dapat menjadi kontra produktif bagi perekonomian nasional.

Selain itu, kebijakan fiskal juga hendaknya memperhatikan stabilitas harga karena kebijakan fiskal yang terlalu terfokus kepada pertumbuhan ekonomi dapat membahayakan kesinambungan pembangunan ekonomi, seperti tercermin dari hasil empiris yang menunjukkan bahwa kebijakan fiskal yang terlalu pro-growth menghasilkan kerugian sosial yang lebih besar. Demikian pula halnya kebijakan moneter hendaknya mempertimbangkan pertumbuhan ekonomi karena kebijakan moneter yang terlalu ketat akan membuat perekonomian nasional akan mengalami tekanan, seperti tercermin dari kerugian sosial yang menjadi lebih besar. 


\section{DAFTAR KEPUSTAKAAN}

Abel, Andrew B. And Ben S. Bernanke. Macroeconomics, Second Edition, Addison-Wesley Publishing Co., 1995.

Ali, Faizul Ariff and T.K. Jayaraman. "Monetary and Fiscal Policy Co-ordination in Fiji". Working Paper 2001/01, May 2001.

Bartolomeo, Giovanni Di and Debora Di Gioacchino. "Fiscal-Monetary Policy Coordination and Debt Management: A Two Stage Dynamic Analysis". Working Paper No. 74, Universita Degli Studi di Roma "La Sapienza" Dipartiento di Economia Pubblica, 2004.

Bennet, Herman dan Norman Loayza. "Policy Biases When The Monetary and Fiscal Authorities Have Different Objectives". Dalam buku Monetary policy: Rules and Transmission Mechanism, edited by Norman Loayza and Klaus Schmidt-Hebbel, Santago, Chile, 2002, Central Bank of Chile.

Faure, Pierre. "Monetary and Fiscal Policy Games and Consequences of Organisational Differences between the European Unio and The Rest of the World". Working Paper Universite Paris XII (Val-de-Marne), et CEFI, 2002.

Javed, Zahoor Hussain and Ahmet Sahinoz. "Interaction of Monetary and Fiscal policy in Case of Turkey". Journal of Applied Science, Asian Network for Scientific Information: 2005.

Labertini, Luca and Ricardo Rovelli. "Optimal Fiscal Stabilization with Credible Central Bank Independence". Working Paper, Department of Economics, University of Bologna, December 21, 2002.

Petit, Maria Luisa. "Fiscal and Monetary Policy Co-Ordination: A Differential Game Approach". Journal of Applied Econometrics, Vol. 4, No. 2 (Apr-Jun., 1989).

Rothenberg, Alexander D. "The Monetary-Fiscal Policy Mix: Empirical Analysis and Theoretical Implications". Working Paper, mimeo, 2004.

Simorangkir, Iskandar. "Koordinasi Kebijakan Moneter dan Kebijakan Fiskal di Indonesia: Suatu Pendekatan dengan Game Theory". PPSK Bank Indonesia Working Paper, 2005.

Traclet, Virginie. "Monetary and Fiscal Policies in Canada: Some Interesting Principles for EMU?". Working Paper 2004-28, Bank of Cananda. 


\section{Lampiran II.1}

\section{Tabel lampiran II.1.1}

Dependent Variable: LOG(CPI)

Method: Least Squares

Date: 11/15/05 Time: 11:51

Sample: 19702004

Included observations: 35

\begin{tabular}{l|l|l|l|l}
\multicolumn{1}{c}{ Variable } & Coefficient & Std. Error & t-Statistic & Prob. \\
\multicolumn{1}{c|}{$\begin{array}{l}\text { LOG(CPI70) } \\
\text { @TREND }\end{array}$} & 1.252917 & 0.058616 & 21.37509 & 0.0000 \\
0.110915 & 0.002857 & 38.82514 & 0.0000 \\
\hline R-squared & 0.978577 & Mean dependent var & 3.093015 \\
Adjusted R-squared & 0.977928 & S.D. dependent var & 1.148913 \\
S.E. of regression & 0.170691 & Akaike info criterion & -0.642477 \\
Sum squared resid & 0.961470 & Schwarz criterion & -0.553600 \\
Log likelihood & 13.24335 & Durbin-Watson stat & 0.268162
\end{tabular}

\section{Tabel lampiran II.1.2}

Dependent Variable: LOG(GDP)

Method: Least Squares

Date: 11/15/05 Time: 11:41

Sample: 19702004

Included observations: 35

\begin{tabular}{|c|c|c|c|c|}
\hline Variable & Coefficient & Std. Error & t-Statistic & Prob. \\
\hline LOG(GDP70) & 1.009037 & 0.002298 & 439.0751 & 0.0000 \\
\hline @TREND & 0.054107 & 0.001454 & 37.20795 & 0.0000 \\
\hline R-squared & 0.976718 & \multicolumn{2}{|c|}{ Mean dependent var } & 13.54527 \\
\hline Adjusted R-squared & 0.976013 & \multicolumn{2}{|c|}{ S.D. dependent var } & 0.561003 \\
\hline S.E. of regression & 0.086887 & \multicolumn{2}{|c|}{ Akaike info criterion } & -1.992977 \\
\hline Sum squared resid & 0.249127 & \multicolumn{2}{|c|}{ Schwarz criterion } & -1.904100 \\
\hline Log likelihood & 36.87710 & \multicolumn{2}{|c|}{ Durbin-Watson stat } & 0.201386 \\
\hline
\end{tabular}




\section{Tabel lampiran II.1.3}

Dependent Variable: LOG(GREAL)

Method: Least Squares

Date: 11/15/05 Time: 11:54

Sample: 19702004

Included observations: 35

\begin{tabular}{l|c|l|l|l}
\multicolumn{1}{c}{ Variable } & Coefficient & Std. Error & t-Statistic & Prob. \\
\multicolumn{1}{c|}{\begin{tabular}{c}
\multicolumn{1}{c}{ LOG(GREAL70) } \\
@TREND
\end{tabular}} & 1.088455 & 0.013063 & 83.32551 & 0.0000 \\
R-squared & 0.074881 & 0.003415 & 21.92813 & 0.0000 \\
Adjusted R-squared & 0.935778 & Mean dependent var & 6.899471 \\
S.E. of regression & 0.933832 & S.D. dependent var & 0.793197 \\
Sum squared resid & 0.204035 & Akaike info criterion & -0.285602 \\
Log likelihood & 1.373803 & Schwarz criterion & -0.196725 \\
& 6.998037 & Durbin-Watson stat & 0.347085
\end{tabular}




\section{Lampiran II.2}

\begin{tabular}{|c|c|c|c|c|c|c|c|c|}
\hline \multicolumn{9}{|c|}{$\begin{array}{c}\text { Tabel lampiran II.2.1 } \\
\text { Perkembangan Beberapa Variabel Makro Ekonomi }\end{array}$} \\
\hline & CPI & GDP & $\mathbf{R}$ & M2 & M1 & APBN & NCG & MO \\
\hline 1970 & 2.62 & 271678.2 & 21.00 & 280.3 & 218.375 & 460.80 & & \\
\hline 1971 & 2.74 & 290760.9 & 21.00 & 401.2 & 290.942 & 533.70 & & \\
\hline 1972 & 2.91 & 311223.6 & 15.00 & 592.9 & 395.317 & 718.00 & & \\
\hline 1973 & 3.82 & 336445.1 & 12.00 & 866.1 & 588.7 & 1103.00 & & \\
\hline 1974 & 5.37 & 362131.6 & 12.00 & 1286.9 & 826.575 & 1857.00 & & \\
\hline 1975 & 6.39 & 380156 & 12.00 & 1760.1 & 1126.25 & 2592.00 & & \\
\hline 1976 & 7.66 & 406335.7 & 12.00 & 2371.4 & 1475.108 & 3375.00 & & \\
\hline 1977 & 8.51 & 441936.1 & 9.00 & 2974.5 & 1905.275 & 3707.00 & & \\
\hline 1978 & 9.20 & 471842.2 & 6.00 & 3500.2 & 2261.458 & 4870.00 & & \\
\hline 1979 & 10.69 & 506401.4 & 6.00 & 4611.5 & 2973.842 & 7284.00 & & \\
\hline 1980 & 12.62 & 556434.2 & 6.00 & 6652.6 & 4365.875 & 10827.00 & 716.48 & 3374.91 \\
\hline 1981 & 14.16 & 600543.6 & 6.00 & 8586.7 & 5672.967 & 14246.00 & 924.79 & 3919.98 \\
\hline 1982 & 15.51 & 614034.5 & 6.00 & 10768.4 & 7123.408 & 13568.00 & 1153.60 & 4106.50 \\
\hline 1983 & 17.33 & 639780.8 & 6.00 & 13015.1 & 7406.166 & 16359.00 & 1520.60 & 5138.20 \\
\hline 1984 & 19.15 & 684408.9 & 16.00 & 16367.2 & 8010 & 16803.00 & 1670.30 & 5700.50 \\
\hline 1985 & 20.05 & 701260 & 18.00 & 20520.5 & 9139.583 & 20770.00 & 1237.30 & 6721.20 \\
\hline 1986 & 21.22 & 742459.3 & 15.39 & 25226.8 & 10634.58 & 24844.00 & 3105.80 & 8170.20 \\
\hline 1987 & 23.19 & 779032.3 & 16.78 & 30249 & 11805.17 & 26056.00 & 3517.60 & 9031.60 \\
\hline 1988 & 25.05 & 824064.3 & 17.72 & 38149 & 13015.67 & 28691.00 & 4426.50 & 8381.40 \\
\hline 1989 & 26.66 & 885511.4 & 18.63 & 48532 & 16050.58 & 32545.00 & 4588.50 & 10788.30 \\
\hline 1990 & 28.74 & 949641.3 & 17.53 & 71078.2 & 22049.58 & 38720.00 & 5221.10 & 12548.70 \\
\hline 1991 & 31.45 & 1015280 & 23.32 & 89299.7 & 24654.92 & 41319.00 & 6258.00 & 12960.70 \\
\hline 1992 & 33.82 & 1081248 & 19.60 & 108140.8 & 27175.67 & 52200.00 & 7976.00 & 16997.00 \\
\hline 1993 & 37.09 & 1151490 & 14.55 & 129598.8 & 32328.25 & 54983.00 & 9013.00 & 18414.00 \\
\hline 1994 & 40.25 & 1238312 & 12.53 & 157075.7 & 40719.92 & 61866.00 & 7510.00 & 23053.00 \\
\hline 1995 & 44.05 & 1340100 & 16.72 & 196025.2 & 47644.58 & 66723.00 & 4672.00 & 27160.00 \\
\hline 1996 & 47.56 & 1444873 & 17.26 & 251318.2 & 56829.5 & 77964.00 & 4269.00 & 36895.00 \\
\hline 1997 & 50.52 & 1512780 & 20.01 & 316160.1 & 67542.5 & 112893.00 & 5470.00 & 51013.00 \\
\hline 1998 & 80.02 & 1314202 & 39.07 & 512663.6 & 100592.3 & 174097.00 & 35700.00 & 90690.00 \\
\hline 1999 & 96.41 & 1324600 & 25.74 & 624151.3 & 109424.3 & 225874.00 & 248095.00 & 125848.00 \\
\hline 2000 & 100.00 & 1389770 & 12.50 & 685880.9 & 134219.8 & 221467 & 233669.00 & 156420.00 \\
\hline 2001 & 111.50 & 1442985 & 15.48 & 786746.8 & 160512.4 & 341563 & 267464.00 & 181508.00 \\
\hline 2002 & 124.75 & 1506124 & 15.50 & 849401.1 & 176190.5 & 322180 & 304058.00 & 179896.00 \\
\hline 2003 & 132.97 & 1579559 & 10.59 & 903958.2 & 198266.3 & 374764 & 260629.00 & 202870.00 \\
\hline 2004 & 141.27 & 1660579 & 6.44 & 970762.4 & 233037.3 & 430000 & 270905.00 & 252236.00 \\
\hline
\end{tabular}

